\title{
Proximate Analysis and Calorific Value of Pellets in Biosolid Combined with Wood Waste Biomass
}

\author{
I Nyoman Sukarta ${ }^{1 *}$, I Dewa Ketut Sastrawidana', Ni Putu Sri Ayuni' \\ 1 Department of Chemistry, Faculty of Mathematic and Natural Sciences, Universitas Pendidikan Ganesha, \\ Singaraja, Bali, Indonesia \\ * Corresponding author's e-mail: nyoman.sukarta@undiksha.ac.id
}

\begin{abstract}
In this study, biosolid and wood waste biomass were used as fuel by turning them into fuel pellets. The purpose of making fuel pellets with various compositions was to compare the type of biosolid pellets and wood waste in terms of proximate testing. The benefits of making biosolid pellets can reduce the landfill waste that contributes to the environmental pollution. The results of this research showed the highest water content that is equal to $10.07 \%$ was found in the wood waste pellets with the composition of (90:10; the highest ash content, amounting to $33.19 \%$ was found in the pellets with the composition of (50:50); the highest value of volatile substances (74.05\%) was contained in pellets with the composition (90:10); the highest value of solid carbon $(10.13 \%)$ was found in the pellets with the composition of (80:20) Meanwhile, the highest calorific value was exhibited by the pellets with the composition of wood waste and biosolid (90:10), equalling $3.822 \mathrm{cal} / \mathrm{g}$.
\end{abstract}

Keywords: biosolids, pellets, proximate and calorific value

\section{INTRODUCTION}

Biosolids are sludge (sludge) that has been processed. Sludge is a byproduct of wastewater treatment. Sludge typically contains $28.75 \%$ solids [Roy et al., 2011]. Therefore, domestic waste sludge is solid, semi-solid, or liquid residue derived from the domestic wastewater treatment. The urban waste sludge constitutes solids generated from the wastewater treatment process that still require further treatment. In this case, biosolids are the sludge that has been stabilized through a process that aims to reduce the pathogenic potential. In the process of wastewater treatment, sludge can be generated either at the primary, secondary, and tertiary processing stage. Thus, the sludge can be generated through the processing of physical, chemical, and biological on the stages of water treatment or wastewater. Nevertheless, sludge which is considered as a biosolids, constituted the sludge that has been processed and produced by the treatment process utilizing aerobic or anaerobic microorganisms.
Biosolids are mainly produced from municipal wastewater treatment, whereas urban waste water mainly comes from the water used in household activities. Several small industries also discharge waste through the channels of urban sewage treatment systems. Besides coming directly from household activities, the wastewater generated from urban waste acumulate (leachate) is also considered as urban waste water. On the basis of these sources, the biosolids composition consists of a mixture of organic matter (volatile matter), inorganic materials (inert material), and water. Volatile organic materials are derived from the decomposition of long chain organic materials such as carbohydrates, fats, proteins found in wastewater. Besides, the organic matter also came from the dead microorganisms. The inorganic material in biosolids generally occurs in the form of mineral metals and heavy metals from soil and sand ending up in the waste stream. The final quality of the produced biosolids depends on the wastewater quality in the processing system. 
Currently, biosolids are generally handled by: applying to an area of land, stockpiling (landfilling), composting, and incineration. In Indonesia, they are mostly used by being applied to an area of land or a landfill. In fact, when viewed from the potential of the main constituent in the form of organic materials, especially organic materials volatile (volatile organic matter), biosolids can be used as an alternative energy source. The existence of biosolids will continue to increase in line with the population and economic growth that occurred today in the developing countries, including Indonesia. On the other hand, the need for energy resources will continue to increase while its availability has become more limited, particularly in relation to fossil fuels. Therefore, the use of biosolids for energy has become a very important effort.

Fuel pellet is a solid material that is crushed and compressed to improve the consistency and efficiency of combustion in relation to their original state [Borowski and Hycnar 2013]. Pellets are generally made from wood waste and agricultural waste which have a high calorific value and low mineral content. In this case, the use of biosolids as a fuel pellet combined with wood waste biomass will be able to compensate for the shortage of the energy potential of biosolids through the form of pellets.

The studies related to the utilization of a variety of biomass waste for fuel pellet have been conducted by numerous scholars: Nielson et al., (2009) studied waste wood as pellets, Fasina and Sokhansanj (1993) examined using peanut shells, Lehtikangas (2001) - using sawdust, and Liu et al. (2012) used logging waste and bark and bamboo. However, not many studies on the use of biosolids as a fuel pellet or fuel derived sludge "sludge derived fuel '(SDF) in the form of pellets have been performed.

The aim of this study was to develop a combination of biosolid and fuel pellet with a wood waste and assess the technical feasibility of utilizing biosolids as a partial substitution of wood pellets. The combustion efficiency and emissions of various ratios of biosolids with wood pellets were measured and compared with wood and bamboo without the addition of biosolids. Proximate analysis was performed on the resulting pellets to determine the potential use of these pellets as an alternative fuel.

\section{MATERIALS AND METHODS}

This study aimed to investigate the relationship between the addition of biosolids in the manufacturing of pellets from biomass with a pellet quality. The materials used for the manufacture of biosolid pellets are biosolid sludge, wood waste, adhesive starch and water as a mixture of glue. The tools used in this study included an electric blender, mesh or filter, mold pellets, small basin, digital scales, bomb calorimeter, high temperature furnace and watch glass.

\section{Proximate Testing}

Proximate Testing includes testing of water content (Mouisture content), ash (Ash Content), volatile matter (Volatile Matter). This testing is conducted by heating or combusting the biosolid pellet in high temperature furnace.

\section{Moisture content}

The calculation of the percentage of water content (Moisture content) in the pellets was carried out using the ASTM D-3173-03 standard with the following equation:

$$
\text { Moisture content } \%=\frac{a-b}{a} \times 100 \%
$$

where: $a=$ biosolid pellets early mass (g)

$b=$ Mass of biosolid pellets after heating $107^{\circ} \mathrm{C}(\mathrm{g})$

\section{The ash content}

Calculation of ash content percentage in biosolid pellets was performed using the ASTM D-3174-04 standard with the following equation:

$$
\text { As content }, \%=\frac{d}{a} \times 100 \%
$$

where: $d=$ Mass pellet after heating to $750^{\circ} \mathrm{C}$ (gram)

\section{Volatile Matter}

The calculation of the percentage content of volatile substances (volatile matter) contained in biosolid pellets was conducted using the ASTM D-3175-02 standard with the following equation:

$$
\text { Volatile matter, } \%=\frac{b-c}{a} \times 100 \%
$$

where: $c=$ Mass biosolid pellet after heating at a temperature of $950^{\circ} \mathrm{C}(\mathrm{g})$ 


\section{Testing calorific value}

The calorific value (heating value) of a fuel is obtained by using a bomb calorimeter. The calorific value obtained by bomb calorimeter is the upper calorific value or the highest heating value (HHV) and lowest heating value (LHV). The calculation of gross calorific value was based on the ASTM D240 standard. By using a bomb calorimeter, the heat absorbed in water in the bomb calorimeter and energy equivalent with HHV and LHV can be calculated. The heat absorbed water in the bomb calorimeter is calculated using the formula:

$$
\mathrm{Q}=\mathrm{m} \cdot \mathrm{Cp} \cdot \Delta \mathrm{T}
$$

where: $Q$ : heat absorbed $(\mathrm{kJ})$

$m$ : Mass of water in the bomb calorimeter (g)

Cp: Specific heat $4.186 \mathrm{~kJ} / \mathrm{kg}{ }^{\circ} \mathrm{C}$

$\Delta T$ : temperature difference $\left({ }^{\circ} \mathrm{C}\right)$

LHV and the HHV is calculated by the following equation:

$$
\mathrm{LHV}=\frac{(m \times c p \times \Delta T)}{m_{\text {pellet }}}
$$

The equation used to calculate HHV:

$$
\begin{aligned}
& \mathrm{HHV}=(\mathrm{T} 2-\mathrm{T} 1-\mathrm{TKP}) \times(\mathrm{CV}(\mathrm{kJ} / \mathrm{kg}) \\
& \mathrm{LHV}=\mathrm{HHV}-3240 \mathrm{~kJ} / \mathrm{kg}
\end{aligned}
$$

Therefore,

$$
\mathrm{HHV}=\mathrm{LHV}+3240 \mathrm{~kJ} / \mathrm{kg}
$$

$T 1=$ temperature of the cooling water at bomb calorimeter before combustion $\left({ }^{\circ} \mathrm{CAL}\right)$

$T 2=$ the temperature of the cooling water bomb calorimeter after burnng $\left({ }^{\circ} \mathrm{C}\right)$

$T K P=$ temperature rise caused by combustion wire

$H H V=$ highest heating value $(\mathrm{kJ} / \mathrm{kg})$

$L H V=$ Lowest heating value $(\mathrm{kJ} / \mathrm{kg})$

\section{RESULT AND DISCUSSION}

\section{Proximate analysis and calorific value}

In order to determine the differences in the quality of pellets produced by the addition of biosolids, the mixing of biomass, i.e. wood waste and biosolids, each with five compositions, was performed. As with raw materials, the pellet quality with five compositions are also characterized by the value of the water content (moisture in air dried sample), ash (ash content), easy fly material (volatile matter), solid carbon (fixed carbon), and calorific value. The data of proximate analysis of biomass pellet wood waste and biosolids produced from each composition are presented in Table 1 below:

Table 1 shows the characteristics of wood waste and biosolid pellets in various compositions, as presented in Figure 1.

From the calculation table of the wood waste and biosolid pellet proximate analysis above, the highest water content (moisture in air dried sample) contained in the pellet with woodwaste and biosolid composition (90:10) in the amount of $10.07 \%$ was obtained. On the other hand, the lowest water content (Moisture in Air Dried Sample), equal to $6.85 \%$, was found in the pellets with the composition of wood waste and biosolid (50:50).

According to Lehtikangas (2001), an average water content of the commercial pelleted product is $10-12 \%$. Low water levels obtained in this study were due to the length of the drying process. Similarly to briquettes, pellets are also made by compaction process. High compaction pressure can also affect the water content of the pellets; by mutually filling the pores of materials, it can reduce the water content in the pores. [Sriharti and Salim, 2011]. In this case, the compaction process is a process of dewatering. In this study, the compaction is performed with a hydraulic jack with the capacity of 3 tons.

Table 1. Proximate analysis and calorific value wood waste and biosolid pellets

\begin{tabular}{|c|c|c|c|c|c|}
\hline $\begin{array}{c}\text { The composition (ratio) of } \\
\text { wood wastes: Biosolid }\end{array}$ & $\begin{array}{c}\text { Moisture in air dried } \\
\text { sample, } \%\end{array}$ & Ash, \% & $\begin{array}{c}\text { Volatile matter, } \\
\%\end{array}$ & $\begin{array}{c}\text { Fixed carbon, } \\
\%\end{array}$ & $\begin{array}{c}\text { Calorific value, } \\
\text { cal/g }\end{array}$ \\
\hline Pellet 1 (90:10) & 10.07 & 6.62 & 74.05 & 9.26 & 3.822 \\
\hline Pellet 2 (80:20) & 9.99 & 12.69 & 67.19 & 10.13 & 3.464 \\
\hline Pellet 3 (70:30) & 9.45 & 18.44 & 63.73 & 8.38 & 3.213 \\
\hline Pellet 4 (60:40) & 6.90 & 27.21 & 57.35 & 8.54 & 2.946 \\
\hline Pellet 5 (50:50) & 6.85 & 33.19 & 52.50 & 7.46 & 2.650 \\
\hline
\end{tabular}




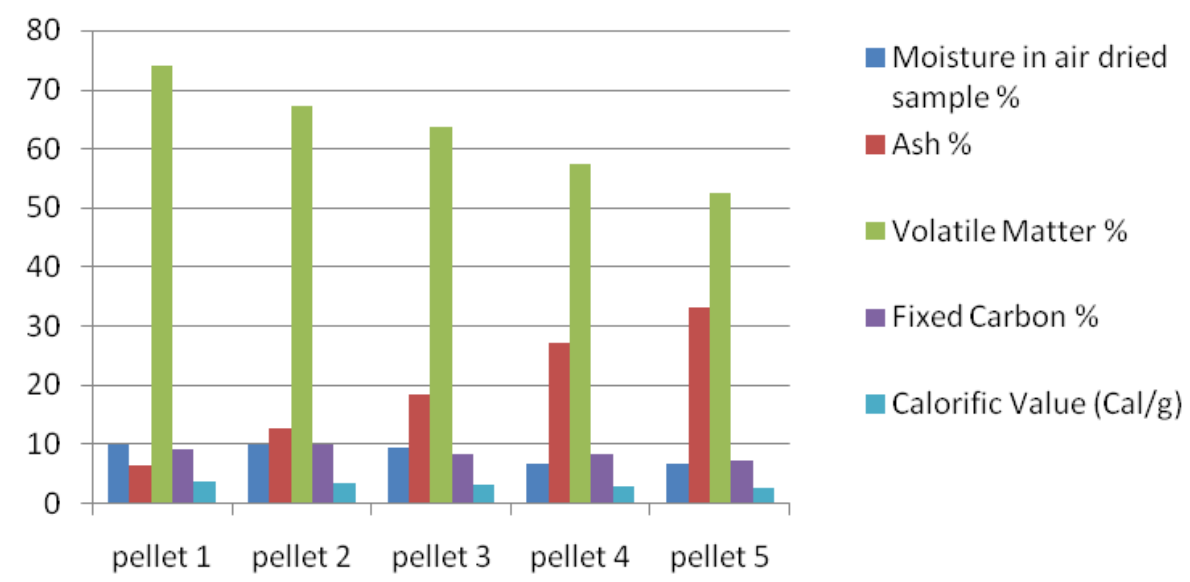

Figure 1. Characteristics of waste wood pellet and biosolids on various compositions

The water content determines the quality pellet as fuel. According to Obernberger et al. (2004), high water content lowers the calorific value, thus reducing the conversion efficiency and performance for the energy that is used to evaporate the water. In addition, it will also prevent further burning. Conversely, low water levels will increase the efficiency and performance and combustion. The water content is the most important characteristic which greatly affects the combustion characteristics of the pellets. The water content also has an influence on the internal temperature changes in the fuel due to evaporation endothermic or because of the total energy required to raise the combustion temperature. During combustion, the water content in the pellet (fuel) will absorb heat for the evaporation process that will significantly reduce the calorific value of pellets. This will lead to a loss of heat or combustion heat to drive the reaction so that the combustion temperature becomes lower. The result will be incomplete combustion of the materials that are volatile and will deposition of unburned carbon (smoke) in the chimney or on the bottom of the cooking tools, such as pots that are relatively difficult to clean, will occur. The existence of significant smoke will impede the flow of the exhaust gas and reduce the heat transfer / heat to the cooking vessel. In addition, the high water levels also cause difficulty in ignition.

\section{Content of ash}

The residue that remains after the combustion of fuel is called ash (ash). The higher the ash content of the fuel, the lower the calorific value of the fuel . Conversely, the lower the ash content of the fuel, the higher the calorific value of the fuel.
Ash was formed from mineral materials which are bound in the structure of the biomass carbon during combustion. In addition, the ash also comprises the impurities from the fuel. The ash content of the fuel is determined by heating the fuel at a temperature of $450-500^{\circ} \mathrm{C}$ for approximately $1 \mathrm{~h}$ (one hour). Ash is a non-flammable material. According to Obernberger et al. (2004) high ash content will result in severe pollution. Stuart et al. (1994) defines ash as the residue remaining after ignition or combustion of a substance at a certain temperature. When the pellet is burned, only slightly volatile substances (volatiles) were retained as ash. Meanwhile, the substances or volatile materials that have a low boiling point will evaporate and become gas.

The highest ash content (ash) in the amount of $33.19 \%$ was found in the pellet with the composition of wood waste and biosolids (50:50), while the lowest that is equal to $6.62 \%$ was observed in the case of $(90: 10)$ composition. This shows that greater content of sludge in the biosolid pellets increase the ash content as well. This occurs because the sludge contains more substances that are more difficult to burn and evaporate, like the mineral that is bound in the structure of the carbon in the sludge; therefore, the combustion of residues produces more ash.

\section{Volatile matter}

The volatile ingredients (volatile matters) are substances that are found in fuels, such as methane, hydrocarbons, hydrogen, carbon monoxide, nitrogen and unburned gases. Volatile materials (VM) are determined by inserting the fuel in the furnace at a temperature of $900 \pm 15^{\circ} \mathrm{C}$ for 15 minutes. The materials that will evaporate when 
the pellets are dried at a controlled temperature are called the volatile content of the pellets. The volatile materials determine the ability of the combustion of a fuel. A fuel with a high content of volatile matters means that most of the calorific value would be released as a vapour combustion (Obernberger et al. 2004).

The highest levels of volatile matter was found on wood waste and biosolid pellets with the composition (90:10), amounting to $74.05 \%$, while the lowest levels of substance volatile matter, equal to $52.50 \%$, were contained in the pellet with the (50:50) composition.

\section{Compact carbon (fixed carbon)}

The carbon content (ultimate carbon content) of a fuel corresponds to the energy content of the fuel. The content of the solid carbon (fixed carbon) fuel is not the same as the ultimate carbon. Solid carbon (fixed carbon) is the carbon that remains after the volatile ingredients (volatile matter) is released from the combustion process. In contrast to ultimate carbon, they are missing along with hydrocarbons due to their volatility. Therefore, the ultimate carbon will determine the amount of carbon dioxide produced during the combustion of a fuel. Fixed carbon (FC) is used as an estimate of the amount of coal that will be generated from the sample of a fuel material. Therefore, fixed carbon is determined by subtracting the mass of volatile matter (VC), moisture content and ash content of the initial mass of a sample of fuel or commonly known as by difference.

The highest levels of carbon (fixed carbon) in the amount of $10.13 \%$ were found in the pellets with the wood waste: biosolids composition (80:20), while the lowest reached 7.46 in the pellets with the (50:50) composition.

\section{Calorific value (calorific value)}

The highest calorific value (calorific value) in this study, in the amount of $3.822 \mathrm{cal} / \mathrm{g}$, was found in the wood waste and biosolid pellets with the composition of $(90: 10)$. On the other hand, the lowest calorific value, equal to $2,650 \mathrm{cal} / \mathrm{g}$, characterized the pellets with (50:50) composition. The heating value is a measure of the energy content of the fuel standard. The heating value is defined as the amount of heat generated when a mass of fuel is burned completely and its combustion products are cooled to $298 \mathrm{~K}$. The heat- ing value is referred to as the gross calorific value (GCV) or higher heating value (HHV) when the latent heat of condensation of water vapour is calculated in the calorific value. However, in the burning of the water content contained in the fuel water vapor is formed, so that heat is not available. This is very useful, because it enables to reduce the water condensation heat of the gross calorific value. The result is known as net calorific value (NCV) or lower calorific value. Water vapour was condensed in a bomb calorimeter, whereas the calorific value was generated using these tools, obtaining the gross calorific value.

\section{CONCLUSION}

On the basis of the research results and discussion it can be concluded that the highest water content value, equal to $10.07 \%$, was contained in the pellet with the composition of wood waste and biosolid (90:10); the highest ash content value $(33.19 \%)$ was contained in the pellets with the (50:50) composition; the highest value of volatile substances contained in the wood waste and biosolid pellets with the composition (90:10) equalled $74.05 \%$, the highest value of solid carbon, equal to $10.13 \%$, was found in the pellets with the composition of $(80: 20)$ that is Meanwhile, the highest calorific value characterized the pellet with the composition of (90:10), equaling $3.822 \mathrm{cal} / \mathrm{g}$.

\section{REFERENCES}

1. Akintunde M.A. And Seriki M.E. 2013. Effect of paper paste on the calorific value of sawdust briquette. International Journal of Advancements in Research \& Technology, 2(1).

2. Borowski G. and Hycnar J.J. 2013. Utilization of fine coal waste as a fuel briquettes. International Journal of Coal Preparation and Utilization, 33(4), 194-204.

3. Demirbas A. 2005. Potential applications of renewable energy sources, biomass combustion problems in boiler power systems and combustion related environmental issues. Progress in Energy and Combustion Science .31, 171-192.

4. Ismaila A., Zakari I.Y., Nasiru R., Tijjani B.I., Abdullahi I., Garba N.N. 2013. Investigation on biomass briquettes as energy source in relation to their calorific values and measurement of their total carbon and elemental contents for efficient biofuel 
utilization. Advances in Applied Science Research, 4(4), 303-309.

5. Jenkins B.M., Baxter L.L., Miles T.R. 1998. Combustion properties of biomass. Fuel Processing Technology. 54. 17-46.

6. Lehtikangas P. 2001. Quality properties of pelletised sawdust, logging residues and bark. Biomass and Bioenergy, 20, 351-360.

7. McKendry P. 2002. Energy production from biomass (part 1): overview of biomass. Bioresource Technology, 83, 37-46

8. Mishra S.L., Sharma S.K., Agarwai R. 2000. Briquetting of lignite for domestic fuel. Journal of Science And Industrial Research, 59, 412-416.

9. Obernberger L and Thek G. 2004. Physical characterisation and chemical composition of densified biomass fuels with regard to their combustion behavior. Biomass and Bioenergy, 27, 653-669.

10. Pallavi H.V., Srikantaswamy S., Kiran B.M., Vyshnavi D.R., Ashwin C.A. 2013. Briquetting agicultural waste as energy source. Journal of En- vironmental Science, Computer Science and Engineering \& Technology, 2(1), 160-172.

11. Poespawati T. and Mustiadi L. 2012. Municipal solid waste densification as an alternative energy. Journal of Energy Technologies and Policy, 2(4).

12. Roy M.M., Dutta A., Corscadden K., Havard P., Dickie L. 2011. Review of biosolids management options and co-incineration of a biosolid-derived fuel. Waste Management, 31, 2228-2235.

13. Rulkens W. 2008..Sewage sludge as a biomass resource for the production of energy: Overview and assessment of the various options. Energy \& Fuels, 22, 9-15.

14. Sheng.C. and Azevedo J.L.T. 2005. .Estimating the higher heating value of biomass fuels from basic analysis data. Biomass and Bioenergy, 28, 499-507.

15. Sriharti Dan Salim T. 2011. Pengaruh komposisi bahanterhadap karakterisasi pellet limbah biji jarak pagar (Jatropha Curcas Linn). Teknologi Indonesia, 34, 40-48. 